\title{
A PRELIMINARY REVISION OF THE GENUS DOCIOSTAURUS, FIEB.
}

\author{
By B. P. Uvarov, \\ Assistant Entomologist, Imperial Bureau of Entomology.
}

The genus Dociostaurus, Fieb., which is synonymous with Stauronotus, Fisch., includes several species of locusts and grasshoppers injurious to agriculture in SouthEastern Europe, Central and Western Asia and North Africa, the well known Moroccan locust (Dociostaurus maroccanus, Thunb.) being one of the worst pests in Algeria, Tunisia, Asia Minor, the Caucasus and Turkestan. The systematics of the species of this genus are in a very unsatisfactory state, and this, together with the tendency of the species to individual variability, is the cause of many mistakes in their identification on the part of economic entomologists. The object of this paper is, therefore, to establish a more or less natural system of the species enabling everyone to identify them with certainty.

The materials upon which this work is based were assembled by me from different. sources. First of all, I have worked out the collection of the Tiflis Museum (Caucasus), where very large series of Dociostaurus species from Transcaucasia and Persia are to be found. Then also the very rich collection of the Turkestan Entomological Station (in Tashkent) was placed at my disposal by the Director of this Station, V. Plotnikov. My friend N. Ikonnikov sent me large series of specimens from Turkestan, Bokhara, and other places, as well as the material in the Museum of Moscow University. The Entomologist of the Entomological Station in BairamAli (Transcaspia), D. A. Smirnov, collected for me in that locality, where I myself had also collected previously. My own collection contains extensive series of this genus taken by myself in Uralsk province (S. E. Russia), Northern Caucasus and Transcaucasia. Very helpful for me was the kindness of Messrs. C. \& I. Bolivar, who sent me for study several Spanish and North African representatives of this genus, as well as the types of species described by I. Bolivar. To all the abovenamed gentlemen I wish to express here my cordial thanks for the loan of material which has enabled me to accomplish this revision.

The genus Dociostaurus was described in June 1853 by Fieber (Lotos, ii, p. 118), and in the same year, but in November, by Fischer (Orthoptera Europaea, pp. 297, 351) under the name Stauronotus; Fischer's name has been generally accepted, but it must give way to Dociostaurus, Fieb., according to the law of priority. W. F. Kirby in his catalogue (Synon. Cat. of Orthoptera, iii, pp. 152-154, 1910) includes in the genus Dociostaurus 12 species. Later on, I. Bolivar described in $1911 \mathrm{D}$. kervillei from Persia and in $1917 \mathrm{D}$. dantini from Morocco; Kirby and Waterhouse included (Fauna Brit. India, Acrid., pp. 117-120, 1914) in this genus five species described by Walker under Stenobothrus. Prof. Stchelkanovzev described in 1909 D. tartarus (Izvestia Varshav. Universit., Warsaw, 1909, p: 34), which is omitted in Kirby's Catalogue. Lastly, F. Werner published in 1913 one more species from Egypt under the name of D. gracilis (Zool. Jahrb., Syst., xxxiv, p. 220). 
Thus the number of species of the genus Dociostaurus reached 19. This number, however, must be reduced to 10 only, since some of the species do not really belong to this genus and others again must be regarded as synonymous, as follows :-

Oedipoda histrio, Fisch. Wald. (Orth. Imperii Rossici, p. 311, pl. 32, fig. 6) belongs, according to Fischer Waldheim, to the section of his genus "Oedipoda" with three keels on the pronotum, the two lateral keels being straight or nearly so; this is not the case in the genus Dociostaurus, one of its chief generic characters being the strongly angulated side keels of the pronotum. I am of opinion that Fischer Waldheim's species is merely one of the numerous colour forms of Calliptamus italicus, $\mathbf{L}$.

All five of Walker's species, as a study of the types in British Museum clearly shows, belong to the genera Aulacobothrus, Bol. and Leva, Bol., and not to Dociostaurus.*

Stauronotus australis, Bol., can hardly belong to this genus, since it is described from tropical West Africa, while all representatives of the genus are palaearctic in their distribution.

Stauronotus hauensteini, Bol., and Stauronotus kervillei, Bol., are synonymous with Dociostaurus crassiusculus, Pantel, as I am convinced from a study of Bolivar's types.

Stauronotus tartarus, Stchelk., is not an independent species, but a geographical race of Dociostaurus crucigerus, Ramb., as is shown below.

Dociostaurus gracilis, Werner, though very unsatisfactorily described, is most likely to be synonymous with $D$.genei, Ocsk.

Unfortunately but few species of this genus (for example, maroccanus) are sharply characterised, while the rest of them are extremely variable individually, their variability being expressed not in coloration or dimensions only, but to some extent in morphological characters as well. In consequence of this, it is quite easy to make mistakes in studying representatives of such extremely variable species as crassiusculus or anatoticus, unless very large series of specimens are available. Though I have been able to study rather long series (more than one thousand specimens altogether), I still think it impossible to give yet a full monograph of the genus, and this revision must be regarded as but a preliminary one.

* The synonymy of these species of Walker's is as follows:-

Leva apicalis (Walker).

1871. Stenobothrus apicalis, Walker, Cat. Derm. Salt. Brit. Mus., v, Suppl., p. 80.

1871. Stenobothrus turbatus, Walker, l.c. p. 81.

1910. Dociostaurus apicalis, Kirby, Syn. Cat. Orth., iii, p. 154, no. 11.

1910. Dociostaurus turbatus, Kirby, l.c., p. 154, no. 12 .

1914. Dociostaurus apicalis, Kirby, Fauna Brit. India, Acrid., p. 117, no. 135, fig. 90.

1914. Dociostaurus turbatus, Kirby, l.c., p. 118, no. 136.

Leva mundus (Walker).

1871. Stenobothrus mundus, Walker, Cat. Derm. Salt. Brit. Mus., v, Suppl., p. 79.

1871. Stenobothrus epacromoides, Walker, l.e., p. 81.

1914. Dociostautus mundus, Kirby, Fauna Brit. India, Acrid., p. 119, no. 137.

1914. Dociostaurus epacromoides, Kirby, l.c., p. 119, no. 138.

? 1918. stauroderus exemplaris, I. Bolivar, Rev. R. Acad. Sc. Madrid, xvi, p. 380.

Aulacobothrus decisus (Walker).

1871. Stenobothrus decisus, Walker, Cat. Derm. Salt. Brit. Mus., v, Suppl., p. 80.

1914. Dociostaurus decisus, Kirby, Fauna Brit. India, Acrid., p. 120, no. 139, fig. 91. 
The genus Dociostaurus is purely palaearctic in its distribution, and none of the species is to be found beyond the borders of the Palaearctic Region. The centre of development of the genus is to be looked for in the dry table-lands of Western and Central Asia, where the largest number of species occurs and where they are especially disposed to individual variability. From there different species spread (and are spreading continually) in all directions, but more especially into the plains of the vast palaearctic desert belt, extending through Northern Africa, and South-western and Central Asia, in the fauna of which species of Dociostaurus present one of the most characteristic features. The distribution of each species will be discussed below in more detail.

Key to the Species.

1(10). Hind femora attenuate, narrow, slightly incrassate at the base. Pronotum constricted in the middle; white stripes not dilated in metazona, or altogether absent.

2 (3). Elytra extending considerably beyond the apex of abdomen. Antennae in both sexes but slightly extending beyond the hind margin of pronotum. Fore tibiae thickened. (Foveolae of the vertex narrowed anteriorly. Front vertical; its ridge above ocellum sulcate in male and plane in female. Hind femora with three very distinct black spots outwardly and black knees. Hind tibiae sanguineous, with base pale.--Length of body, 0 20-28, ㅇ 28-38; of elytra, ơ 20-27, 우25-36 ; of hind femora, ơ 15, 우 $20 \mathrm{~mm}$.)

1. maroccanus, (Thunb.)

3 (2). Elytra not or scarcely reaching the apex of hind femora. Antennae of male one and half times or even twice as long as the head and pronotum taken together; antennae of female extending considerably beyond the hind margin of pronotum. Fore femora not thickened.

4 (5). Head not at all or but slightly prominent above pronotum. Foveolae of the vertex longer than wide. Front in male slightly inclined, with flat ridge, in female vertical with ridge convex above ocellum. Elytra reaching the apex of hind femora. Hind femora with three sharp black spots

2. crucigerus (Ramb.).

$a(d)$. Hind tibiae red. Black marks very distinct.

$b(c)$. General habitus slender; head not thick. (Length of body, o 14-16, 우 18-23; of elytra, ơ 9-11, 우 15-17 ; of hind femora, of 10, 우 $13 \mathrm{~mm}$.)

2a. crucigerus crucigerus (Ramb.).

$c(b)$. General habitus more clumsy ; head thick. (Length of body $ð 12-16$, 우 20-24; of elytra ơ 8-10, 우 12:5-15; of hind femora of 10.2, 우 12-15

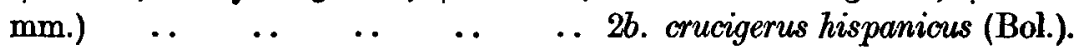
$d(a)$. Hind tibiae pale. Coloration more or less pale, with the black and white markings indistinct or totally absent. (Dimensions as in crucigerus) 2c. crucigerus tartarus (Stchelk.).

5 (4). Head very prominent above, especially in male. Foveolae of the vertex as long as wide. Front in male strongly, in female markedly reclinate. Elytra not or scarcely reaching the apex of hind femora. 
6 (7). Occiput without carina in its middle. Hind tibiae bluish. Foveolae of the vertex not narrowed anteriorly. (Antennae in both sexes one and half times as long as head and pronotum together. General coloration pale greyish, with grey markings ; hind femora with rather distinct grey spots.Length of body, o 12, 오 15-17; of pronotum, o 2-3, 우 3 ; of elytra, o 10-12, q 13-14; of hind femora, o 6-7, q 9-11 mm.) . . 3. genei (Ocsk.).

7 (6). Occiput with a short but distinct longitudinal carina in the middle.

8 (9). Small, slender. Foveolae of the vertex strongly narrowed anteriorly. Frontal ridge in male impressed along its whole length, in female quite flat. Hind tibiae yellowish or bluish, without dark ring near the base. (General coloration brownish grey or clay-coloured. Antennae in male twice, in female one and half times as long as head and pronotum together. Wings hyaline or bluish.-Length of body, ô 12-14, 우 13-16; of elytra, ơ 7-10, ㅇ 11-13; of hind femora, ఫึ 8-10, 우 11-13 mm.)

4. albicornis (Eversm.).

$9(8)$. Larger and heavier built. Foveolae of the vertex not or but slightly narrowed anteriorly. Frontal ridge in male quite flat, in female convex above ocellum, but flat and disappearing below it. Hind tibiae greyish, bluish or rose, with a black or dark ring near the base. (General coloration very variable. Antennae in male twice as long as in female but a little longer than head and pronotum together. Wings rosy or bluish.-Length of body, o 18-27. \& 23-32; of elytra, of 12-16, \& 15-20; of hind femora, o $12-15$, ㅇ $15-20 \mathrm{~mm}$.). . . . . . . $\quad 5$. anatolicus (Krauss).

10 (1). Hind femora short, wide, rather incrassate at the base. Pronotum cylindrical, not constricted in the middle; white stripes in metazona dilated.

11(14). Rather slender, with head prominent above. Hind tibiae never red.

12(13). Foveolae of the vertex longer than wide, not narrowed anteriorly, and contiguous at the apex. Frontal ridge in ma!e plane, with slight impression below ocellum (female unknown). (Black markings on pronotum and hind femora sharp. Hind tibiae yellowish - Length of body, $\delta 12.5$; of elytra, $\AA 55$; of hind femora, $0^{\star} 9 \mathrm{~mm}$.) . . . $\quad 6$. dantini, Bol.

13(12). Foveolae of the vertex nearly as long as wide, narrowed anteriorly. Frontal ridge in male sulcate for its whole length, in female flat and slightly impressed near ocellum. (General coloration clay-like, with very indistinct castaneous markings. Hind tibiae bluish.-Length of body, $\delta 14, q 21$; of elytra, $\delta^{\star} 5-8$, ㅇ $8-15$; of hind femora, $\$ 10$, $\$ 14 \mathrm{~mm}$.)

7. plotnikori, sp. n.

14(11), Clumsy, with thick head, not prominent above. Hind tibiae red or sanguineous.

15(18). Lateral carinae of pronotum present not only on metazona, but also on fóre part of prozona. $\delta^{*}$ : anal segment with two large rounded contiguous lobes behind, covering the base of the supra-anal plate; the latter rounded, with apex attenuate. $q$ : anal segment far wider than long; supra-anal plate triangular, its length equal to its basal width. .Hind tibiae coral-red. 
16(17). Smaller. Foveolae of the vertex distinctly impressed, markedly narrowed anteriorly. Front rather reclinate; frontal ridge in profile straight. (Yellowish-grey or clay-coloured, with more or less distinct grey and pale markings ; lateral lobes of pronotum with a black square spot in the middle. Antennae in male one-half, in female slightly, longer than head and pronotum together. Elytra not longer than abdomen, but very often far shorter.-Length of body, $\approx 12-18$, ㅇ 18-26; of elytra, $\delta 7-11$, 우 9-18; of hind femora, o 9-10, ㅇ 12-15 mm.) .. 8. crassiusculus (Pantel).

17(16). Larger. Foveolae of the vertex but slightly impressed, nearly square. Front nearly vertical; frontal ridge in profile convex. (Straw-yellow, with sharp grey and black markings. Antennae in female as long as head and pronotum together, in male a little longer. Elytra reaching the middle of abdomen.-Length of body $\delta 23$, $q 32$; of elytra, $\delta 8, q 13$; of hind

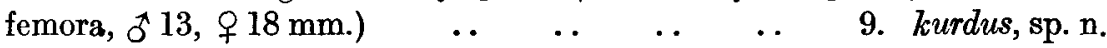

18(15). Lateral carinae of the pronotum present on metazona only. $\delta$ : anal segment with two small, widely separated lobes behind; supra-anal plate triangular, not attenuate at the apex. $q$ : anal segment as long as wide; supra-anal plate longer than its basal width. Hind tibiae sanguineous. (Clayish grey or brown, dull, with indistinct grey and pale markings. Lateral lobes of pronotum with a small square black spot in the middle. Elytra reaching the apex of abdomen.-Length of body, ox 16-18, $q 23-25$;

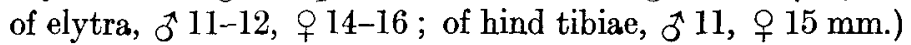

10. kraussi (Ingen.).

Annotated Catalogue of Species.

1. Dociostaurus maroccanus (Thunb.).

1815. Gryllus maroccanus, Thunberg, Mém. Acad. Petersb., v, p. 244.

1824. Gryllus maroccanus, Thunberg, l.c., ix, pp. 399, 425, no. 91.

1825. Gryllus cruciatus, Charpentier, Horae Entom., p. 137.

1832. Oedipoda cruciata, Brullé, Exped. Morée, Ins., p. 92, no. 63, pl. 30, fig. 2.

1836. Acrydium cruciatum, Costa, Fauna Regni Napoli, Acrid., p. 37, no. 17, pl. 5, fig. $1, A, b, c$.

1846. Oedipoda vastator, Fischer Waldheim, Orth. Imp. Ross., p. 312, no. 30, pl. 14, fig. 1.

1853. Dociostaurus cruciata, Fieber, Lotos, iii, p. 118 (partim).

1853. Stauronotus cruciatus, Fischer, Orth. Europ., p. 352 (partim), pl. 17, fig. 11, a,b.

1854. Dociostaurus cruciata, Fieber, Syn. Eur. Orth., p. 18, no. 1 (partim).

1873. Stauronotus maroccanus, Stål, Rec. Orth., p. 111, no. 1.

1882. Stauronotus maroccanus, Brunner v. Wattenwyl, Prodr. Europ. Orth., p. 136, no. 1.

1910. Dociostaurus maroccanus, Kirby, Syn. Cat. Orth., iii, p. 152, no. 1.

This species was described by Thunberg in 1815 and 1824, and redescribed twice since-by Charpentier as Gryllus cruciatus* and by Fischer Waldheim as Oedipoda

* I am obliged to Dr. W. Ramme, who kindly studied for me Charpentier's type of oruciatus in the Berlin Museum and informed me that it is identical with maroccanis, Thunb. 
vastator. Fieber and Fischer evidently described this species (under cruciatus) together with crucigerus of Rambur, which is a quite distinct species; and the same mistake has been repeated even by Brunner, who says that maroccanus is a very variable species, which is not the case. In fact, I had the opportunity of studying many hundreds of specimens from different localities and may say that the individual or geographical variability in this species is extremely small, and it is very constant in all its characters. It can very easily be recognised by the aid of the key given above. From its nearest relative, $D$. crucigerus, it may be distinguished by its long elytra, short antennae and thickened (in males) fore femora, besides its different dimensions. It is interesting to mention that females during the period of oviposition gradually change their coloration, which becomes dull clay-coloured, the black markings turning to light brown. This coloration might be regarded as protective while the female is sitting on the ground, but it is more likely to depend on physiological causes. The coloration of the males changes in this period as well, but to a far less degree.

Geographical Distribution. The range of distribution of the Moroccan locust includes North Africa, Southern Europe, Syria, Palestine, Arabia, Mesopotamia, Asia Minor, Armenia, Persia and the Aralo-Caspian plains. Within this vast region there are to be found several places where this species finds most favourable natural conditions and where it becomes a serious pest of agriculture, breeding in large masses and acquiring swarming habits.*

2. Dociostaurus crucigerus (Ramb.).

1838. Gryllus crucigerus, Rambur, Faune Entom. d'Andal., ii, p. 86, no. 13.

1848. Oedipoda brevicollis, Eversmann, Addit. quaedam laevia ad Fisch. Wald. celeb. Orth. Ross., p. 11, tab. A, fig. 4.

1853. Dociostaurus cruciata, Fieber, Lotos, iii, p. 118 (partim).

1853. Stauronotus cruciatus, Fischer, Orth. Europ., p. 352 (partim).

1853. Stauronotus crucigerus, Fischer, l.c., p. 356, no. 5.

1854. Dociostaurus cruciata, Fieber, Syn. Europ. Orth, p. 18, no. 1 (partim).

1859. Stauronotus cruciatus, Eversmann (nec Charp.), Bull. Soc. Nat. Moscow, xxxii (1), p. 137.

1860. Stauronotus genei, Türk (nec Ocsk.), Wien. Ent. Mon., iv, p. 86, no. 3.

1862. Stauronotus annulipes, Türk, l.c. vi, p. 81.

1867. Stauronotus brevicollis, Frivaldsky, Ertek Termész. Kör., i (12), p. 162, no. 1, pl. 6, fig. 10.

1882. Stauronotus brevicollis, Brunner v. Wattenwyll, Prodromus Europ. Orth., pp. 136, 137, no. 2 , pl. 5, fig. 30 , A, B.

1910. Dociostaurus brevicollis, Kirby, Syn. Cat. Orth., iii, p. 153, no. 4.

Rambur's description of Gryllus crucigerus leaves no doubt that he had before him not $D$. maroccanus, Thunb. (known at that time as cruciatus, Charp.), but. another species distinguished by its smaller size, shorter elytra and with the lateral carinae of the pronotum present on the prozona as well as on the metazona-i.e.

* The biology of $D$. maroccanus is fully described by W. La Baume in a recently published book. 
the species described ten years later by Eversmann as Oedipoda brevicollis. Afterwards, however, Fieber and Fischer, who evidently did not know Rambur's species, confused it, as well as brevicollis, Ev., with cruciatus, Charp. (maroccanus, Thunb.).

This miscomprehension of crucigerus has been accepted by all following writers; even Eversmann himself in 1859 regarded his brevicollis as synonymous with cruciatus, Charp. Later on brevicollis, Ev., was raised to specific rank by Frivaldsky (1867), but the identity of brevicollis and crucigerus, Ramb., has never been recognised. Rambur's name, however, has ten years priority over brevicollis and must therefore be adopted. The same species has been again described in 1860 by Türk under Stauronotus genei (nec Ocsk.), and two years later the author changed this name, as preoccupied by Ocskay, into annulipes.

This species in its typical form is easily recognisable from its nearest relative-maroccanus-by the characters given above, which are very constant.

Geographical distribution. The area of distribution of this species occupies the southern (Mediterranean) parts of Europe, South Russia, Southern Siberia, Turkestan, Transcaspia, the Caucasus, Asia Minor, Persia and North Africa. It is to be mentioned, however, that the species is to be sub-divided into three different geographical races (subspecies), as follows :-

\section{2a. Dociostaurus crucigerus hispanicus, Bol.}

1898. Stauronotus brevicollis var. hispanicus, I. Bolivar, Ann. Sci. Nat. Porto, v, p. 14.

This subspecies, peculiar to Spain, is distinguished from the typical form by its more heavy habitus and especially its thick head (thanks to the kindness of Messrs. Bolivar I have had the opportunity of studying this form). It would be of interest to examine a large series of specimens from Southern France, whence Rambur's type came. If specimens from this locality are identical with hispanious, then the Eastern European form, which I take now for the typical, must have another name, and brevicollis, Ev., might be applied to it as a subspecific name.

\section{2b. Dociostaurus crucigerus crucigerus, Ramb.}

The typical form occurs over the whole of Southern Europe, South Russia, Caucasus (except the Eastern plains of Ciscaucasia and Transcaucasia) and Southern. Siberia.

\section{2c. Dociostaurus crucigerus tartarus, Stschelkan.}

1909. Stauronotus tartarus (Sauss. in litt.), Stschelkanovzev, Izvestia Imper. Varshav. Univers., Warsaw, 1909, p. 34, no. 22.

\section{-. Stauronotus genei, auctorum (nec Ocsk.), partim.}

This south-eastern desert subspecies is easily recognised by the colour of its hind tibire, as well as the rather indistinct and extremely variable general coloration. On account of its pale tibiae it is very often confused with $D$. genei, Ocsk., which has good morphological differences from it. The area of distribution of this race lies in desert plains of the Aralo-Caspian basin, Persia, Mesopotamia and Northern Africa ; in fact it populates the whole Eremian subregion of the Palaearctic Region. 
B. P. UVARov.

The economic importance of Dociostaurus crucigerus, with its subspecies, is not so great as that of maroccanus, since it is a non-swarming and non-migratory species, but still it is one of the injurious grasshoppers and does some damage to grass and corn crops in Spain and Western Siberia, together with different species of Stenobothrus and other grasshoppers.

\section{Dociostaurus genei (Ocsk.).}

1832. Gryllus genei, Ocskay, Acta Acad. Leop.' Carol, xvi (2), p. 961.

1853. Acridium pygmaeum (Bonelli in litt.), Fischer, Orth. Europ., pp. 352, 353, tab. xvii, fig. 11c, 11d.

1910. Dociostaurus genei, Kirby, Syn. Cat. Orth. ii, p. 154, no. 8.

? 1913. Dociostaurus gracilis, Werner, Zoolog. Jahrb., Syst., 34, p. 220.

Closely related to albicornis, Ev., but always recognisable by the lack of the longitudinal carina on the vertex. From $D$. crucigerus tartarus it may be distinguished by the prominence of the upper part of the head.

Geographical Distribution. This is not quite clear, since the species has been often confused with albicornis and crucigerus tartarus, but it seems that it is a native of the desert plains of Western Asia and North Africa, occurring also in some isolated places in Southern Europe.

There is nothing known about the economic importance of this species.

\section{Dociostaurus albicornis (Eversm.).}

1848. Stauronotus albicornis, Eversmann, Addit. quaedam laevia ad Fisch. Wald. Orth. Ross., p. 10, no. 6, pl. A, fig. 3.

1910. Dociostaurus albicornis, Kirby, Syn. Cat. Orth., iii, p. 157, no. 9.

Though the difference between albicornis and genei is rather considerable, it seems desirable that an examination should be made of large series of specimens of both species, which may then prove to be conspecific.

Geographical Distribution. Not so extensive as that of genei, since it is known only from the Aralo-Caspian basin; its occurrence in Germany, recorded by Azam (Bull. Soc. Ent. France, 1913, p. 218) is almost certainly based on a wrong determination or a mistake in date.

The economic importance of this species is unknown.

\section{Dociostaurus anatolicus (Krauss).}

1896. Stauronotus anatolicus, Krauss, Zoolog. Jahrb., Syst., ix, p. 560, no. 7, pl. 8, fig. 1.

1896. Stauronatus anatolicus var. castaneopicta, Krauss, l.c., p. 562, no. 7a, pl. 8, fig. $2,2 \mathrm{~A}, \mathrm{~B}$.

1907. Stauronotus anatolicus var. castaneopicta, Adelung, Horae Soc. Entom. Ross., xxxviii, p. 51, no. 10, pl. 1, fig. 2.

1910. Dociostaurus anatolicus, Kirby, Syn. Cat. Orth., iii, p. 153, no. 7. 
An extremely variable species in its size, relative dimensions and coloration. The form described and figured by Krauss and Adelung under the name v. castaneopicta is remarkable for the coloration of the head and especially of the pronotum and elytra, on which large velvet-castaneous spots are to be seen on a straw-yellow ground.

Geographical Distribution. D. anatolicus occurs in Asia Minor, Eastern and Southern Transcaucasia, the whole Aralo-Caspian basin and Persia.

In some localities of Turkestan it occurs in large quantities, though it does not form swarms, and may cause some damage to grass; no attacks on cultivated crops, however, have been recorded.

6. Dociostaurus dantini, I. Bol.

1914. Dociostaurus dantini, I. Bolivar, Mem. R. Soc. Españ. Hist. Natur., viii (5a), p. 186.

A very distinct species, as I have been able to ascertain by a study of the unique type specimen.

Geographical Distribution. Described from Morocco.

\section{Dociostaurus plotnikovi, sp. nov.}

The short diagnosis of this new species given above may be completed by the following description:-

Form slender. General coloration clay-yellow, with obsolete grey markings. Head elongate, prominent above (especially in male) ; eyes elongate; front in male strongly reclinate and wholly sulcate, in female markedly reclinate, flat, with a slight impression near the ocellum. Antennae in male one and half times as long as head and pronotum together, in female only a little longer. Foveolae of the vertex markedly impressed, nearly as long as wide, narrowed in front. Typical sulcus of pronotum placed behind the middle; hind margin of pronotum rotundate; disk obsolete castaneous (very often only in metazona) with pale lateral cross-shaped lines, which are triangularly widened on the metazona; lateral lobes with an obliterated grey or castaneous spot in the middle. Elytra about as long as abdomen, unicolorous or with scarcely distinct grey spots. Hind femora with typical spots greyish, obsolescent. Hind tibiae bluish or pale. $\delta$ : anal segment with two small rotundate widely separated lobes; supra-anal plate rotundato-triangular; subgenital plate short, with blunt apex, very hairy. $q$ : anal segment wider than long ; supra-anal plate rotundato-triangular. (Dimensions, see Key.)

Geographical Distribution. This species has been sent to me from the Turkestan Entomological Station by the Director, V. Plotnikov, from Turkestan (Golodnaya Steppe) and Bokhara (Mirshade-Karatag), where it occurs sometimes in considerable quantities, and its larvae even form migrating swarms, causing damage to different cultivated crops.

\section{Dociostaurus crassiusculus (Pant.).}

1886. Stauronotus orassiusculus, Paritel, Ann. Soc. Esp. Hist. Nat., xv, p. 237, pl. 2, fig. 1 . 
1893. Stauronotus hauensteini, Bolivar, Rev. Biol. Nord. France, v, p. 480.

1894. Stauronotus hauensteini, Giglio-Tos, Boll. Mus. Torino, ix (191), p. 2.

1896. Stauronotus hauensteini, Krauss, Zoolog. Jahrb., System., ix, p. 562, nn. 9, pl. 8 , fig. 3.

1898. Stauronotus crassiusculus, Bolivar, Ann. Sci. Nat. Porto, v, p. 13, 14.

1902. Stauronotus crassiusculus, Navas, Bol. Soc. Esp. Hist. Natur., ii, p. 335, no. 3.

1910. Dociostaurus hauensteini, Kirby, Syn. Cat. Orth., iii, p. 153, no. 2.

1910. Dociostaurus crassiusculus, Kirby, l.c., p. 153, no. 6.

1911. Dociostaurus kervillei, Bolivar, Bull. Soc. Sci. Nat. Rouen, xlvii, p. 36.

1913. Stauronotus crassiusculus, Pant., var. cappadocicus, Azam, Bull. Soc. Ent. France, 1913, p. 219.

D. crassiusculus, Pantel, was described from Spain, and hauensteini, Bol., from Asia Minor, but I have most carefully studied topotypic specimens of both species and could not find any difference between them. I had very large series of this species from Asia Minor, Transcaucasia and Persia, which enable me to state that it is very variable in its dimensions and coloration, though not in morphological characters, which are very stable. D. kervillei, described by Bolivar more recently, is but a small and rather light-coloured form of the same species, as I am convinced from a study of the type specimen. The variety described by Azam is a mere individual aberration which is not worth a distinctive name.

Geographical Distribution. This is as yet not fully known. It seems that this species has two separate areas of distribution : one in Spain and another in Western Asia (Asia Minor, Armenia, Eastern Transcaucasia, Persia, Syria); but it is quite possible that it occurs in North Africa as well. If even these two areas are actually separated, there is nothing unnatural in such distribution of a species, since we know that there existed once a closer connection between the eastern and western parts of the Mediterranean countries than is now the case.

There are no records concerning the economic importance of this species.

\section{Dociostaurus kurdus, sp. nov.}

There is nothing to be added to the short diagnosis of this species given above, since it agrees in all essential characters with $D$. crassiusculus, the differences being given in the key to the species. These differences are, in fact, so few that I should have been inclined to treat kurdus as only a geographical form of crassiusculus were it not that it has also some important morphological features, and I prefer to regard it in the meantime as a distinct species.

Geographical Distribution. I had a number of specimens of both sexes from Muséék and Vezne, in Kurdistan, taken by P. Nesterov in June and July 1914.

\section{Dociostaurus kraussi (Ingen.).}

1897. Stauronotus kraussi, Ingenitsky, Horae Soc. Entom. Ross, xxxi, p. 63, pl. 7. 1910. Dociostaurus kraussi, Kirby, Syn. Cat. Orth., iii, p. 153, no. 3. 
This species is very well characterised by numerous morphological features, and is quite easy to recognise. It is not very variable in dimensions and little more so in coloration, but all the morphological characters are very constant.

Geographical Distribution. D. kraussi is distributed all over the Kirghiz Steppes (north from the Caspian Sea), Turkestan, Transcaspia, Eastern Ciscaucasia and Southwestern Siberia. In the latter country it is one of the commonest grasshoppers, being sometimes very injurious to pastures and corn crops.

A supplement to the synonymy of Dociostaurus maroccanus, Thunb.

In the course of rearranging the collection of Locustidae in the British Museum, I came across the type of Epacromia oceanica, Walker (Cat. Derm. Salt. Brit. Mus., iv, p. 779, No. 26, 1870), which has been included by Kirby (Syn. Cat. Orth., iii, p. 193, No. 12) in the genus Chortoicetes, but is undoubtedly conspecific with $D$. maroccanus. The type specimen of $E$. oceanica bears the label "Sandw. I., Beechey"; but there are in the British Museum a few more undoubtedly palaearctic species bearing the same label, and the only explanation is that these specimens have been taken during Capt. Beechey's journey from Europe, via the Canaries, to the Sandwich Islands, most probably at the Canaries or at Madeira, and that they have been wrongly labelled. 